\title{
Théophile Gautier în epoca romantismului plasticizat și „sterilizat”
}

\author{
Prof. univ. dr. Daniel GĂLĂȚANU \\ Universitatea „Dunărea de Jos” din Galați; \\ Membru al Groupe de Recherche Identités et \\ Cultures al Universității din Le Havre, Franța
}

\begin{abstract}
The purpose of this article is the aesthetic, literary and stylistic analyze of Théophile Gautier's youth poems and his evolution from the romanticism, whose fervent defender and supporter he was, at the beginning, wearing the red vests of the battle for Hernani, alongside the great Hugo, toward the brink of the stylistic perfection of his Émaux et Camées (Enamels and Cameos) Parnassian era. His formal perfection, plastic poetry (let us not forget that the poet had flirted all his lifetime with the painting, nor that he was a great admirer of the Spanish "shades" painters) and absolute beauty obsession, key elements of the Parnassian doctrine, was manifested in Gautier's art since his "romantic" youth, and this is exactly the thesis to be proved of this research. In the later stage of his creative evolution, Gautier will become even one of the founding fathers of the Parnassian movement, thus creating premises for the emergence of the poetic modernity started with and by Baudelaire.
\end{abstract}

Key words: Gautier, French poetry, stylistics, romanticism, Parnassian movement.

Observam în ultimul meu studiu dedicat romantismului ${ }^{1}$ că aproape toți maeștrii săi se îndepărtează, mai mult sau mai puțin hotărât, în jurul mijlocului secolului al XIX-lea, de acest curent, tendința culminând cu Théophile Gautier, care-l atacă în însăși fibra sa doctrinară. O primă explicație a acestui fenomen al istoriei literare franceze, foarte la îndemână, ar fi că marii artiști sunt prea mari

1 GALATANU, Daniel, Préromantisme et Romantisme dans la poésie française des XVIIIe et XIXe siècles, Presses Académiques Francophones, OmniScriptum GmbH, Saarbrücken, 2015,

https://www.presses-

academiques.com/catalog/search/https://portal.dnb.de/opac.htm?query=daniel+galatanu \&method=simpleSearch. 
pentru a se lăsa identificați cu un singur curent artistic și/sau doctrinar. Dar aș îndrăzni, cum spuneam în concluziile versiuni românești² a acestui studiu, să avansez o altă ipoteză și, în acest sens, cred că cea mai potrivită explicație ar fi că romantismul a fost întotdeauna un corp străin, perceput ca alogen, în marele organism de factură clasică al spiritualității franceze. Doamna de Staël, cea care a introdus romantismul în Franța, pare să fi fost învinsă cu propriile ei arme pe pământul patriei sale, de către marii poeți ai curentului pe care l-a inaugurat ea însăși, ca și cum sistemul imunitar al spiritualității franceze s-ar fi apărat împotriva acestei invazii a virusului cultural provenind Din Germania... Marele strigăt al lui Elie Faure: „Franța nu ar fi Franța fără romantismul francez!”3 nu-și găsește sensul decât după elaborarea „operei integratoare a atotputernicului Titan al Romantismului francez, căci fără Victor Hugo, acest curent de sorginte germanică nu ar fi avut nici o șansă de a fi cu adevărat asimilat nici în spiritualitatea franceză, nici în subconștientul francezilor și, cu atât mai puțin, în sufletul lor. În cele din urmă, cine ar fi crezut că Franța se va lăuda vreodată cu Romantismul său național și chiar va deveni vreodată exportatoare de Romantism, căci Franța zilelor noastre se laudă nu doar cu Romantismul hugolian, cum spuneam, de factură națională, ci și cu cel tenebros, al lui Nerval și care va crea o adevărată școală la nivel mondial, exportat fiind, deci, până în America lui E. A. Poe?!"

Voi încerca să analizez acum, în limba română, operele perioadei romantice, "de tinerețe" a celui care a adus sfârșitul propriu-zis, estetic și doctrinar, al romantismului poetic francez și, care a fost, la început, unul din cei mai entuziaști susținători ai săi, Théophile Gautier, cel care a și elaborat, de altfel, chiar o Istorie a Romantismului francez ${ }^{5}$. Ca și când inaderența parțială a marelui Musset la romantism nu ar fi fost de ajuns, o altă tânără speranță a curentului, un alt copil teribil, ajunge să trădeze definitiv această mișcare. Prieten cu Nerval și cu Borel, pasionat dintotdeauna de pictură (cu care a și cochetat toată viața sa) și de o anumită viziune plastică care a și inundat, de altfel, întreaga sa operă literară și asta în toate etapele și epocile creației sale, Théophile Gautier a fost, la începuturi, un romantic pur și dur. Cele mai

2 GALATANU, Daniel, Momentele impunerii sensibilității romantice în poezia franceză, Zigotto, Galați, 2016, pp. 190-191.

3 FAURE, Elie, L'histoire de l'art, (traducere în limba română de Irina Mavrodin), Meridiane, București, 1970, p. 78.

${ }^{4}$ GALATANU [2016], p. 191.

${ }^{5}$ GAUTIER, Théophile, Istoria Romantismului, Allfa, Bucuresti, 1998. 
importante istorii literare dedicate secolului al XIX-lea ${ }^{6} \hat{1} l$ prezintă pe acesta - și-1 prezintă întotdeauna în capitolele dedicate parnasianismului, nu romantismului - ca pe un viteaz apărător al dramei romantice, aparținând taberei lui Hugo și arborând frenetic și plin de entuziasm sfidătoarea vestă roșie, cu ocazia celebrei bătălii cauzată de Hernani. Totuși, inaderența acestui „fiu al Greciei antice și al tinerei Franța", cum îi spunea Hugo ${ }^{7}$, se manifesta deja încă din prima parte a tinereții sale, cu o ironie fină și vizibil antiromantică: „Era la modă pe vremea aceea, în întreaga școală romantică, să fii palid, livid, verzui, un pic cadaveros, dacă se putea. Asta dădea aerul fatal, byronian,...devorat de pasiuni și de remușcări."8 Acest aer fatal și pasional, 1-a impresionat, în realitate, foarte mult pe Gautier, la începuturile sale și inspirația byroniană nu a întârziat să producă efecte.

În lungul său poem fantastic, de peste 200 de versuri, cu evidente și puternice influențe din Byron și din Musset, Albertus (1832), Gautier reface povestea tânărului pictor care se lasă damnat pentru o vrăjitoare:

Le diable éternua. - Pour un nez fashionable

L'odeur de l'assemblée était insoutenable.

- Dieu vous bénisse, dit Albertus poliment.

- À peine eut-il lâché le saint nom, que fantômes,

Sorcières et sorciers, monstres follets et gnomes,

Tout disparut en l'air comme un enchantement.

- Il sentit plein d'effroi des griffes acérées,

Des dents qui se plongeaient dans ses chairs lacérées ;

Il cria ; mais son cri ne fut point entendu...

Et des contadini le matin, près de Rome,

6 Cf. MITTERAND, Henri, RINCE, Dominique \& LECHERBONNIER, Bernard, Littérature - textes et documents - XIXe siècle, Nathan, Paris, 1986, RINCE, Dominique, La Poésie romantique, Nathan, Paris, 1983, TIEGHEM Van, Le Romantisme dans la littérature européenne, A. Michel, 1969 și, desigur, monumentala SABATIER, Robert, Histoire de la poésie française du XIXe siècle, Albin Michel, Paris, 1975.

${ }^{7}$ Cf. MITTERAND, Henri, RINCE, Dominique \& LECHERBONNIER, Bernard, op. cit., p. 279.

8 Apud LAGARDE, A. \& MICHARD, L., Anthologies et histoire littéraire, XIXe siècle, Bordas, Paris, 1967, p. 263. 
Sur la voie Appia trouvèrent un corps d'homme,

Les reins cassés, le col tordu. ${ }^{9}$

Regăsim în acest mic fragment, fantasticul și tenebrosul univers obsesional romantic (Vrăjitor și vrăjitoare, monștri grotești și gnomil Totul dispăru ca printr-o vrajă.), punctat cu neologisme barbare (un nas fashionable) și a cărui ton general, „palid, livid, verzui, un pic cadaveros” este obținut prin sfâșierea monstruoasă a cărnii umane (El simți plin de spaimă ghearele ca niște cuțite,/ Dinți care se înfingeau în cărnurile sfâșiate; [...] un corp de bărbat,/ Cu șalele rupte, cu gâtul sucit."). Lipsite de originalitate și, trebuie s-o spunem sincer, fără prea mare valoare literară, poemele din tinerețe ale lui Gautier (înaintea lui Albertus, el își publicase în 1830 culegerea de Poezii), nu puteau să-i mulțumească în nici un fel evidentele sale porniri rafinate.

În acest fel, poetul pleacă în căutarea unui alt drum, drum care-l va conduce tocmai în Spania, exact ca în cazul lui Musset. Gautier produce deci, cam în 1845, o savuroasă culegere de poeme „hispanizante”, încă romantice, dar nu în totalitate, celebra sa España, în care el amestecă în mod savant descrierea peisajelor cu cea a operelor de artă. Iată o piesă din această culegere, picturală și semnificativă, poemul Pinii din Lande:

Sans regretter son sang qui coule goutte à goutte,

Le pin verse son baume et sa sève qui bout,

Et se tient toujours droit sur le bord de la route,

Comme un soldat blessé qui veut mourir debout.

Le poète est ainsi dans les Landes du monde ;

Lorsqu'il est sans blessure, il garde son trésor.

Il faut qu'il ait au cour une entaille profonde

Pour épancher ses vers, divines larmes d'or!

Deja simbolic, aproape simbolist, acest poem vorbește despre condiția poetului în lumea contemporană (pe vremea aceea, ca și în zilele noastre) care, după modelul pelicanului mussetian, trebuie să accepte neapărat să-și verse

\footnotetext{
${ }^{9}$ Toate poemele lui Gautier citate în acest studiu sunt extrase din : GAUTIER, Théophile, CEuvres poétiques complètes, Bartillat, 2004. Acestea pot fi gasite și la adresele : http://poesie.webnet.fr/poemes/France/gautier/85.html și https://gallica.bnf.fr/essentiels/gautier/emaux-camees
} 
sângele care curge picătură cu picătură. Nobil și stoic în suferința sa, exact ca în cazul lui Vigny, poetul trebuie să accepte să se sacrifice în numele artei: Pinul își varsă balsamul și seva ce se scurgel Ca un soldat rănit care vrea să moară în picioare. Totuși, chiar în mijlocul acestei tirade tipic romantice și în esența sa și în ritmul derulării sale și care transmite această idee atât de dragă artiștilor romantici, conform căreia nu poate exista artă fără sacrificiu, așa cum nu există perle fără rănile dureroase acoperite cu sideful produs de stridiile rănite, vedem deja apărând materiile nobile și „divine” ale parnasianismului: Trebuie să ai în inimă o tăietură adâncăl Pentru a-ți lăsa să curgă versurile, divine lacrimi de aur!

$\mathrm{Nu}$ doar aurul prețios îi bântuie conștiința lui Gautier, ci și operele de artă, pânzele maeștrilor spanioli, Zurbaran și Ribeira. În poemul omonim dedicat acestuia din urmă, poetul francez amestecă tonurile întunecate ale tristei iubiri pentru urât cu lumina splendidului azur a cerului italian (fără a o putea găsi pe aceasta din urmă în universul tenebros și opresiv a pictorului spaniol):

Il est des cours épris du triste amour du laid.

Tu fus un de ceux-là, peintre à la rude brosse

Que Naples a salué du nom d'Espagnolet.

Rien ne put amollir ton âpreté féroce,

Et le splendide azur du ciel italien

$N^{\prime}$ a laissé nul reflet dans ta peinture atroce.

Ce-ar putea fi mai romantic decât acest puternic contrast între luminile și umbrele acestui pictor cu pensula groasă și căruia nimic n-ar putea să-i înmoaie hotărârea feroce? Gautier laudă virtuțile „negre” și tenebroase ale romantismului, punându-le în evidență în tablourile pictorului spaniol:

Il te faut des sujets sombres et violents

Où l'ange des douleurs vide ses noirs calices,

Où la hache s'émousse aux billots ruisselants.

Mais tu ne sus trouver que du rouge de sang,

Et quand du haut des cieux apportant l'auréole,

Sur le front de tes saints l'ange de Dieu descend,

En détournant les yeux, il la pose et s'envole!

Observăm, totuși, în această vervă dezlănțuită a subiectelor sumbre și violente (În care îngerul durerii își golește negrele potire, I In care securea se umple de spume pe tocătoarele năclăite), un suflu nou, o tentație nouă din înaltul cerurilor ceși poartă cu mândrie aureola. Și această tentație este, fără nici o îndoială, legată de perfecțiunea și de perfecționismul „divin” și rece ale parnasianismului. 
Atitudinea lui Gautier față de romantism pare, într-adevăr, cea a îngerului lui Dumnezeu: el coboară pentru a încorona și a recunoaște astfel valoarea, această valoare a subiectelor sumbre și violente, fără să-i placă totuși și fără chiar să poată suporta urâtul și tenebrosul: Întorcându-și privirea, o așează și își ia zborul!

În tenebrele lui Ribeira, Gautier se îndreaptă în chiar aceeași culegere de versuri, España, înspre latura pitorească a romantismului, pe care o și inundă cu simbolurile artei sublime, ale artei pure, neavând alt scop, nici social, nici politic, decât propria sa frumusețe și, deci, în deplin consens cu doctrina parnasiană.

În ciuda acestei trădări, parțiale, a romantismului, trebuie să-i recunoaștem lui Gautier enormul său merit în evoluția poeziei franceze și universale. Bogăția sa tematică, permanenta căutare a perfecțiunii formale și virtuozitatea sa poetică, (care inhibă uneori, din păcate, sensibilitatea și fantezia sa naturale și care provin din „pur-sângele” său romantic) deschid, toate trei, calea spre apariția parnasianismului, dar și, deși indirect, calea spre prima modernitate poetică franceză, inaugurată de Baudelaire - cel care i-a și dedicat lui Théophile Gautier, de altfel, "florile [sale] maladive" - și continuată de întreg simbolismul.

\section{BIBLIOGRAFIE:}

BALACI, Alexandru, Avatarurile lui Gautier in Studii si note literare, Ed. Eminescu, Bucuresti, 1979;

FAURE, Elie, L'histoire de l'art, (traducere în limba română de Irina Mavrodin), Meridiane, București, 1970, p. 78;

GAUTIER, Théophile, Istoria Romantismului, Allfa, Bucuresti, 1998;

GAUTIER, Théophile, CEuvres poétiques complètes, Bartillat, 2004;

LAGARDE, A. \& MICHARD, L., Anthologies et histoire littéraire, XIXe siècle, Bordas, Paris, 1967;

MICLĂU, Paul, Le Poème moderne, E.U.B., Bucarest, 2001;

MITTERAND, Henri, RINCE, Dominique \& LECHERBONNIER, Bernard, Littérature - textes et documents - XIXe siècle, Nathan, Paris, 1986;

GĂLĂȚANU, Daniel, La ville romantique dans la poésie française in Les Cahiers du GRIC, Editions de l'Université du Havre, numéro 6, septembre 2008;

GĂLĂȚANU, Daniel, Préromantisme et Romantisme dans la poésie française des XVIIIe et XIXe siècles, Presses Académiques Francophones, OmniScriptum $\mathrm{GmbH}$, Saarbrücken, 2015; 
GĂLĂȚANU, Daniel, Momentele impunerii sensibilității romantice în poezia franceză, Zigotto, Galați, 2016;

RIFFATERRE, Michael, Sémiotique de la poésie, Seuil, Paris, 1983;

RINCE, Dominique, La Poésie romantique, Nathan, Paris, 1983;

SABATIER, Robert, Histoire de la poésie française du XIXe siècle, Albin Michel, Paris, 1975;

TIEGHEM Van, Le Romantisme dans la littérature européenne, Albin Michel, 1969.

\section{SITOGRAFIE:}

https://www.poesie-francaise.fr/theophile-gautier-emaux-et-camees

https://gallica.bnf.fr/essentiels/gautier/emaux-camees http://fr.wikipedia.org/wiki/Parnasse (litt\%C3\%A9rature)

http://poesie.webnet.fr/poemes/France/gautier/85.html

https://www.pressesacademiques.com/catalog/search

https://portal.dnb.de/opac.htm?query=daniel+galatanu\&method=simple $\underline{\text { Search }}$

https://gric.univ-lehavre.fr/spip.php?rubrique63

https://gric.univ-lehavre.fr/spip.php?article5 